\title{
Perancangan Alat Simulasi Sistem Kendali Lampu Rumah Menggunakan Aplikasi Android
}

\author{
Muhammad Syahputra Novelan \\ Universitas Pembangunan Panca Budi, Medan, Indonesia \\ Email: putranovelan@dosen.pancabudi.ac.id
}

\begin{abstract}
Abstrak
Smartphone dengan sistem operasi Android semakin banyak tersedia di pasaran dengan harga yang semakin terjangkau. Sistem operasi Android sendiri bersifat sistem operasi open source yang dapat dimodifikasi sesuai dengan keperluan. Dalam penelitian ini bertujuan merancang dan mengimplementasikan, yaitu sistem kendali lampu rumah mengaktifkan dan menonaktifkan lewat smartphone dengan memanfaatkan bluetooth dan menjadikan android sebagai perangkat seluler yang multifungsi, di samping alat komunikasi tapi juga sebagai perangkat yang dikomunikasikan untuk mengendalikan sebuah perangkat keras. Berdasarkan hasil pengujian yang dilakukan, sistem dapat bekerja dengan baik sesuai dengan tujuan program aplikasi lampu control yang dibuat dapat dijalankan di sistem operasi Android, dan dapat mengaktifkan dan menonaktifkan perangkat driver lampu. Komunikasi data antara perangkat driver lampu dengan smartphone android berjalan dengan baik, Jarak jangkau sistem aplikasi kendali dapat mengontrol perangkat driver lampu tergantung spesifikasi perangkat bluetooth yang digunakan baik dari sisi penerima dan pengirim
\end{abstract}

Kata Kunci : Smartphone, Android, Sistem Kendali, Bluetooth

\begin{abstract}
Smartphones with the Android operating system are increasingly available in the market at increasingly affordable prices. The Android operating system itself is an open source operating system that can be modified according to needs. In this research, the aim is to design and implement a home lighting control system that activates and deactivates via a smartphone using Bluetooth and makes Android a multifunctional cellular device, in addition to a communication device but also as a device that is communicated to control a hardware device. Based on the results of tests conducted, the system can work properly in accordance with the goals of the lamp control application program that is made to run on the Android operating system, and can activate and deactivate the lamp driver device. Data communication between the lamp driver device and the Android smartphone runs well, the range of the control application system can control the lamp driver device depending on the specifications of the Bluetooth device used both from the receiver and sender side
\end{abstract}

Keywords : Smartphone, Android, Full Control System, Bluetooth 


\section{PENDAHULUAN}

Pada umumnya sekarang ini masih banyak dijumpai pengendali saklar lampu yang dilakukakan secara manual sehingga menyebabkan penggunaan alat - alat listrik tidak terkontrol dengan baik, misalnya penggunaan alat - alat yang dijalankan oleh tenaga listrik pada rumah, sekolah, kampus atau perusahaan yang terdiri dari beberapa banyak ruangan, akan menimbulkan masalah jika dalam pengontrolan menghidupkan dan mematikan peralatan tersebut dalam hal ini lampu listrik yang ada di setiap ruangan dilakukan secara manual. Sebagai contoh dapat dilihat pada pengendalian nyala padamnya lampu pada setiap ruangan yang terdapat di beberapa tempat yang terpisah, akan membutuhkan tenaga manusia. Untuk mengatasi masalah ini perlu adanya perencanaan yang tepat, sehingga timbul pemikiran saya untuk membuat alat pengontrolan lampu nyala padamnya lampu ruangan menggunakan Smartphone Android. Dengan sistem pengontrolan ini diharapkan dapat meningkatkan efisiensi penggunaan energi listrik dan meningkatkan efisiensi kerja manusia sehingga lebih mengefisiensikan waktu. Dengan memanfaatkan perangkat keras yang sudah terdapat di ponsel Smartphone Android berupa pengaturan bluetooth maka dapat membuat aplikasi berdasarkan fungsi tersebut. Selain itu dalam proses pembuatan aplikasi tentunya tidak berbayar dan dapat dilakukan dengan bebas atau open source dan memiliki tampilan aplikasi yang bisa dimengerti pemakaiannya oleh pengguna.

\section{Defenisi}

\subsection{Arduino Uno}

Menurut Abdul Kadir (2013 : 16), Arduino Uno adalah salah satu produk berlabel arduino yang sebenarnya adalah suatu papan elektronik yang mengandung mikrokontroler ATMega328 (sebuah keping yang secara fungsional bertindak seperti sebuah komputer). Piranti ini dapat dimanfaatkan untuk mewujudkan rangkaian elektronik dari yang sederhana hingga yang kompleks. Pengendalian LED hingga pengontrolan robot dapat diimplementasikan dengan menggunakan papan berukuran relatif kecil ini. Bahkan dengan penambahan komponen tertentu, piranti ini bisa dipakai untuk pemantauan kondisi pasien di rumah sakit dan pengendalian alat-alat di rumah. (Sumber: B. Gustomo, 2015).

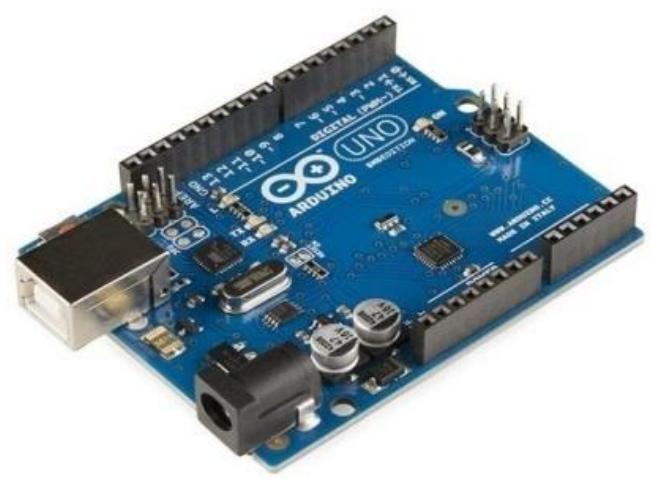

Gambar 1 Bentuk Fisik Arduino Uno

\subsection{Program Arduino Ide}

Kode Program Arduino biasa disebut sketch dan dibuat menggunakan bahasa pemrograman C. Program atau sketch yang sudah selesai ditulis di Arduino IDE bisa langsung dicompile dan diupload ke Arduino Board. 


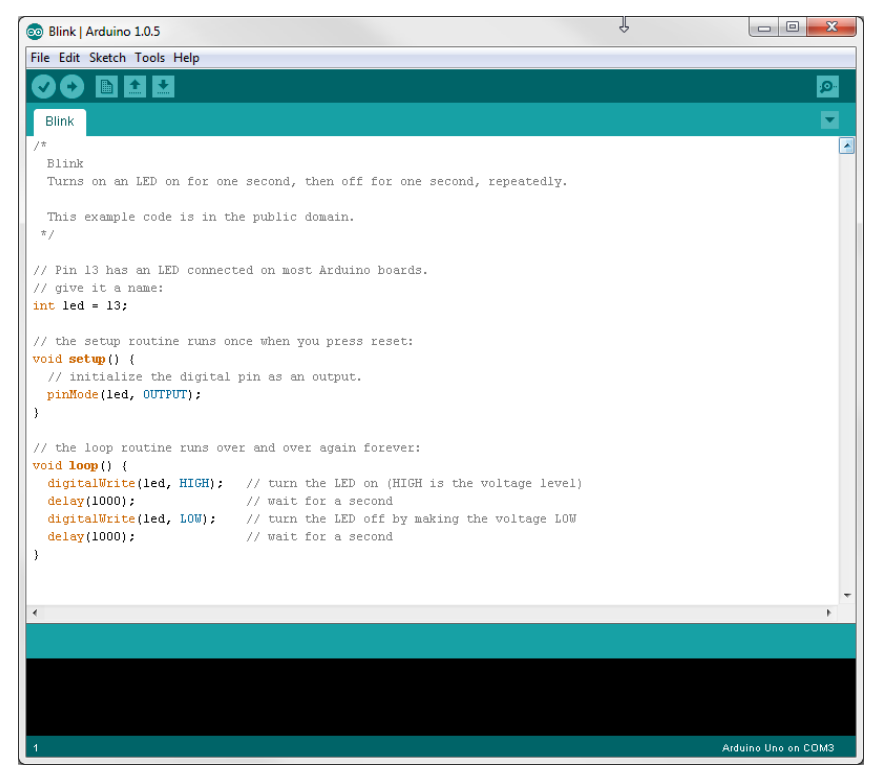

Gambar 2 Tampilan Program Arduino Uno

Secara sederhana, sketch dalam Arduino dikelompokkan menjadi 3 blok (lihat gambar di atas):

\section{Header}

Pada bagian ini biasanya ditulis definisi-definisi penting yang akan digunakan selanjutnya dalam program, misalnya penggunaan library dan pendefinisian variable. Code dalam blok ini dijalankan hanya sekali pada waktu compile. Di bawah ini contoh code untuk mendeklarasikan variable led (integer) dan sekaligus di isi dengan angka 13 int led $=13$.

\section{Header}

Di sinilah awal program Arduino berjalan, yaitu di saat awal, atau ketika power on Arduino board. Biasanya di blok ini diisi penentuan apakah suatu pin digunakan sebagai input atau output, menggunakan perintah pinMode. Initialisasi variable juga bisa dilakukan di blok ini // the setup routine runs once when you press reset: void setup() \{ // initialize the digital pin as an output. pinMode(led, OUTPUT); \} OUTPUT adalah suatu makro yang sudah didefinisikan Arduino yang berarti $=1$. Jadi perintah di atas sama dengan pinMode(led, 1); Suatu pin bisa difungsikan sebagai OUTPUT atau INPUT. JIka difungsikan sebagai output, dia siap mengirimkan arus listrik (maksimum $100 \mathrm{~mA}$ ) kepada beban yang disambungkannya. Jika difungsikan sebagai INPUT, pin tersebut memiliki impedance yang tinggi dan siap menerima arus yang dikirimkan kepadanya.

\section{Loop}

Blok ini akan dieksekusi secara terus menerus. Apabila program sudah sampai akhir blok, maka akan dilanjutkan dengan mengulang eksekusi dari awal blok. Program akan berhenti apabila tombol power Arduino di matikan. Di sinilah fungsi utama program Arduino kita berada. void loop() \{ digitalWrite(led, HIGH); // nyalakan LED delay(1000); // tunggu 1000 milidetik digitalWrite(led, LOW); // matikan LED delay(1000); // tunggu 1000 milidetik \} Perintah digitalWrite(pinNumber,nilai) akan memerintahkan arduino untuk menyalakan atau mematikan tegangan di pinNumber tergantung nilainya. Jadi perintah di atas digitalWrite(led,HIGH) akan membuat pin nomor 13 (karena di header dideklarasi led = 13) memiliki tegangan $=5 \mathrm{~V}(\mathrm{HIGH})$. Hanya ada dua kemungkinan nilai digitalWrite yaitu HIGH atau LOW yang sebetulnya adalah nilai integer 1 atau 0 . Kalau sudah dibuat program diatas, 
selanjutnya kita ambil kabel USB yang diikutsertakan pada saat membeli Arduino, pasangkan ke komputer dan board arduino, dan upload programnya. Lampu LED yg ada di Arduino board kita akan kelap-kelip. Sekedar informasi, sebuah LED telah disediakan di board Arduino Uno dan disambungkan ke pin 13. Selain blok setup() dan loop() di atas kita bisa mendefinisikan sendiri blok fungsi sesuai kebutuhan. Kita akan jumpai nanti pada saat pembahasan proyek. (Septa Ajjie, 2016).

\subsection{Modul Bluetooth HC-05}

HC-05 merupakan modul bluetooth kelas 2 berbasis Bluetron BTR310 yang memiliki jangkauan sinyal hingga $10 \mathrm{~m}$. Modul ini berfungsi sebagai initiator (device yang memulai koneksi) maupun acceptor (device yang menerima koneksi). Catu daya modul sebesar 3,3 - 5 VDC. AT Command digunakan sebagai protokol komunikasi dengan host (mikrokontroler / PC) dan sebagai pemberi instruksi setting modul bluetooth. Modul ini dapat diaplikasikan dalam sistem transmisi data nirkabel (Agus Mulyanto, 2017).

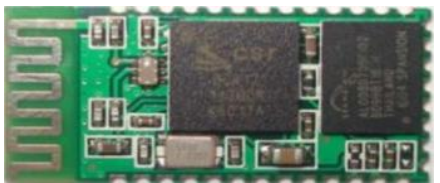

Gambar 3 Modul Bluetooth HC-05

\section{HASIL DAN PEMBAHASAN}

Hasil dari pengujian yang dilakukan adalah sebuah perangkat lunak android yang dirancang dengan menggunakan aplikasi Eclipse dan alat yang dibuat atau dirancang dan di program dengan menggunakan aplikasi Arduino Ide. Berikut in adalah tampilan hasil aplikasi android dan pembahasan dari sistem kendali lampu menggunakan smartphone Android. Sebelum masuk ke tampilan hasilnya adapun proses struktur jalannya program yang di gambarkan dalam bentuk flowchart.
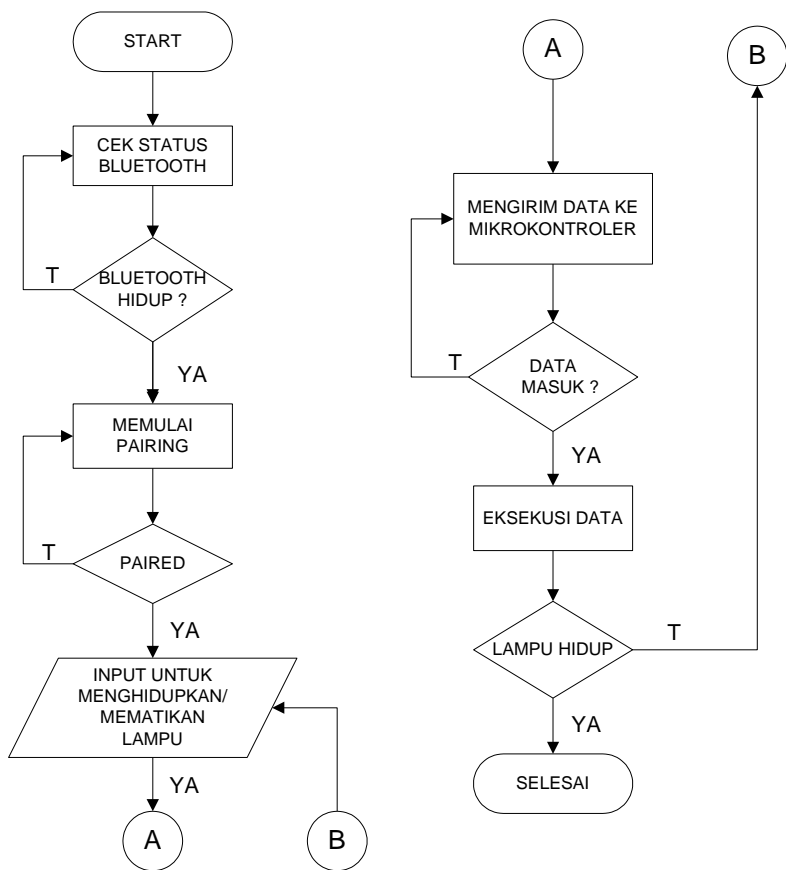

Gambar 4 Flowchart Sistem Kendali Lampu 
Flowchart yang diawali dari Start yaitu dengan menjalankan bluetooth yang ada di smartphone Android kemudian bluetooth akan memulai pairing atau disebut juga dengan memulai pemasangan atau menghubungkan antara bluetooth smartphone ke modul bluetooth HC-06. Bluetooth yang dihubungkan di mikrokontroler menggunakan bluetooth HC-06. Setelah kedua bluetooth terhubung, aplikasi smartphone mengirim data ke mikrokontroler dengan menginputkan data untuk menghidupkan dan mematikan lampu. Mikrokontroler merupakan sebagai pusat sistem kendali seluruh sistem yang ada. Setelah data diterima oleh mikrokontroler maka secara otomatis lampu akan hidup tetapi jika data yang di inputkan salah maka lampu tidak akan hidup.

\subsection{Implementasi}

Pengujian merupakan tahap uji coba terhadap sistem yang telah dibuat apakah sistem sudah berjalan dengan benar. Sedangkan implementasi merupakan pengetesan sistem dengan menggunakan data yang sesungguhnya dalam jangka waktu tertentu yang dilakukan oleh analis sistem bersama dengan user.

\subsection{Halaman utama}

Halaman utama merupakan halaman awal yang akan muncul apabila program dijalankan. Pada halaman ini user dapat memilih menu apa yang diinginkan. Tampilan Halaman Utama dapat dilihat pada gambar 5 berikut ini.

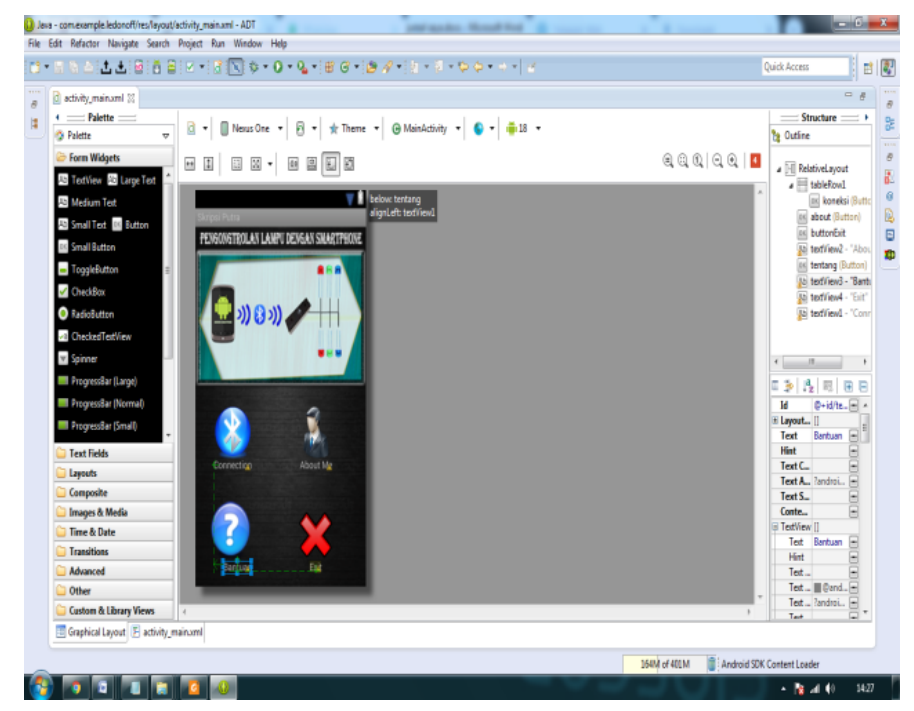

Gambar 5 Halaman Menu Utama

\subsection{Halaman Connection}

Pada halaman ini terdapat beberapa jenis tombol On dan tombol Off yang berfungsi untuk menghidupkan dan mematikan beberapa lampu yang terkoneksi ke bluetooth. Tampilan Connection dapat dilihat pada gambar 6 


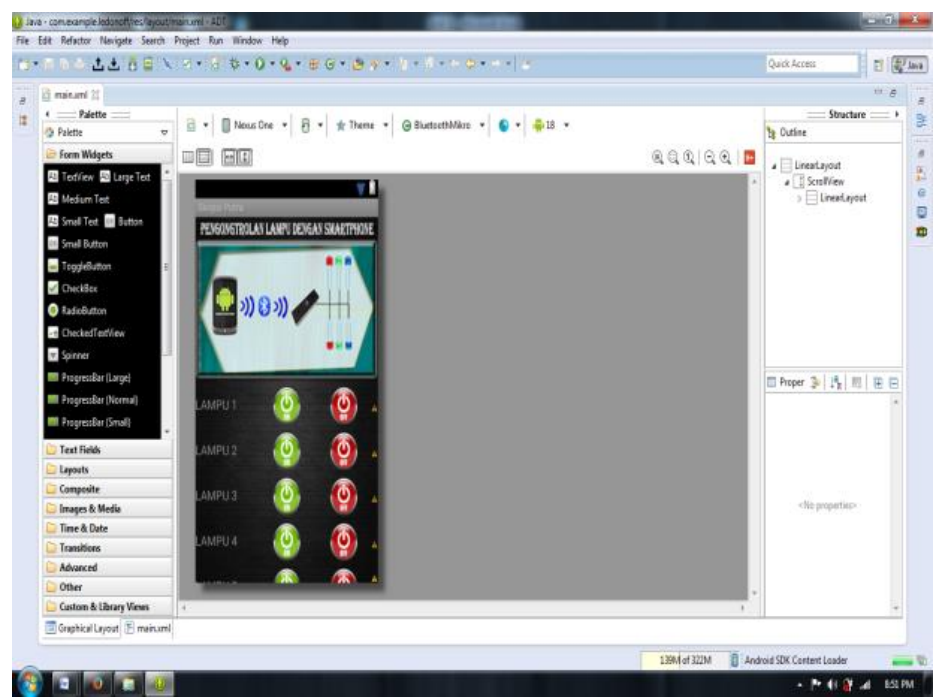

Gambar 6 Halaman Connection

\subsection{Halaman Bantuan}

Pada Halaman ini terdapat tata cara untuk menjalankan aplikasi yang di rancang di program Eclipse. Tampilan Bantuan dapat dilihat pada gambar 7

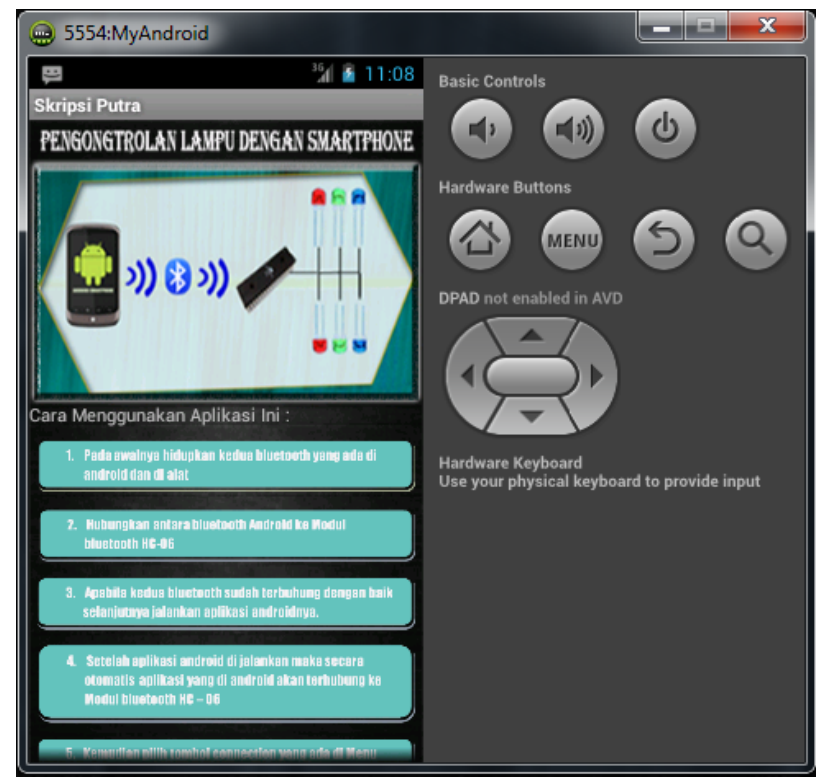

Gambar 7 Halaman Bantuan

Setelah perangkat hardware diprogram ke mikrokontroler maka secara otomatis program sudah masuk ke mikrokontroler. Untuk selanjutnya hubungkan bluetooth yang ada di Android ke Module bluetooth HC-06 kemudian jalankan program aplikasi Android dan tekan tombol $O n$ maka lampu rumah akan hidup dan jika di tekan tombol Off maka lampu rumah secara otomatis akan mati. Berikut adalah gambar pada saat lampu rumah hidup, ditunjukkan pada gambar 8: 


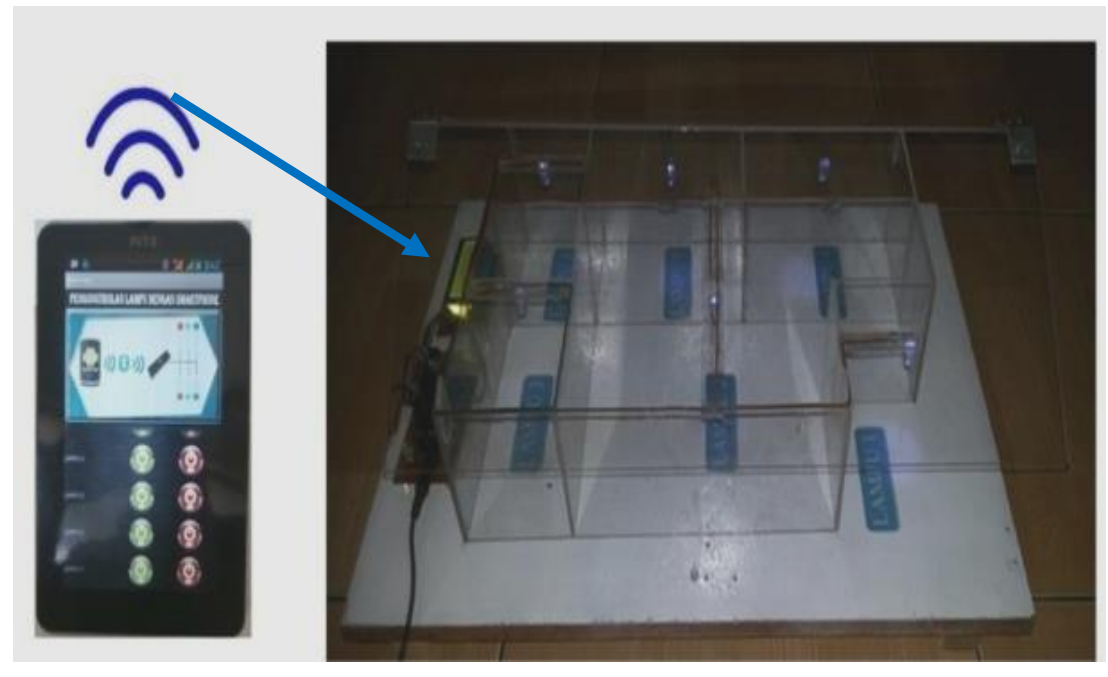

Gambar 8 Halaman Lampu Pada Saat Hidup

Pada gambar 8 menunjukkan bagaimana proses kerja dari rangkaian pengontrol lampu sehingga dapat menghidupkan dan mematikan lampu rumah. Pada saat aplikasi android ini ditekan tombol nya pengiriman data dikirim melalui frekuensi gelombang radio pada frekuensi $2.4 \mathrm{GHz}$.

Pada aplikasi Android yang di buat dengan menggunakan program aplikasi Eclipse Tombol On yang pertama berisikan angka karakter 1. Maka untuk menghidupkan lampu 1 karakter tersebut diubah menjadi gelombang elektromagnetik yang dikirim oleh Bluetooth client (handphone), ketika diterima oleh Bluetooth server (Module Bluetooth HC-06) maka data yang berbentuk gelombang elektromagnetik tersebut diubah kembali menjadi karakter 1 , kemudian karakter 1 tersebut diubah dalam bentuk sinyal digital dan pada mikrokontroler telah diprogram bahwa karakter 1 tersebut merupakan karakter untuk menghidupkan lampu.

Pengujian ini dilakukan untuk menghidupkan alat dan mencoba melakukan pairing antara modul bluetooth dengan bluetooth pada smartphone. Pengujian ini dilakukan untuk mengetahui berapa jarak maksimal yang dapat dilakukan dan untuk melakukan pairing antar bluetooth kemudian menghidupkan dan mematikan lampu. Hasil pengujian jarak konektifitas alat pengontrol lampu menggunakan bluetooth tanpa penghalang ini dapat dilihat pata tabel 1.

Tabel 1. Hasil Pengujian Konektifitas Bluetooth Tanpa Penghalang

\begin{tabular}{|c|c|c|c|}
\hline No & Jarak & Hasil & Keterangan \\
\hline 1. & 2 Meter & Berhasil terkoneksi & Semua lampu menyala \\
\hline 2. & 3 Meter & Berhasil terkoneksi & Semua lampu menyala \\
\hline 3. & 4 Meter & Berhasil terkoneksi & Semua lampu menyala \\
\hline 4. & 5 Meter & Berhasil terkoneksi & Semua lampu menyala \\
\hline 5. & 6 Meter & Berhasil terkoneksi & Semua lampu menyala \\
\hline 6. & 7 Meter & Berhasil terkoneksi & Semua lampu menyala \\
\hline 7. & 8 Meter & Berhasil terkoneksi & Semua lampu menyala \\
\hline 8. & 9 Meter & Berhasil terkoneksi & Semua lampu menyala \\
\hline 9. & 10 Meter & Gagal terkoneksi & Semua lampu menyala \\
\hline
\end{tabular}

Dari pengujian jarak ini didapatkan hasil dimana koneksi bluetooth akan terkoneksi dengan baik pada jarak 10 meter tanpa penghalang, jika terdapat penghalang koneksi hanya 
sebatas 9 meter, hasil ini dapat dilihat pada tabel 2 namun alat ini tidak dapat terkoneksi jika alat terdapat dilantai yang berbeda atau lebih dari 9 meter dengan penghalang karena kemampuan sinyal bluetooth untuk menembus benda padat sangat lemah.

Tabel 2. Hasil Pengujian Konektifitas Bluetooth Ada Penghalang

\begin{tabular}{|c|c|c|c|}
\hline No & Jarak & Hasil & Keterangan \\
\hline 1. & 2 Meter & Berhasil terkoneksi & Semua lampu menyala \\
\hline 2. & 3 Meter & Berhasil terkoneksi & Semua lampu menyala \\
\hline 3. & 4 Meter & Berhasil terkoneksi & Semua lampu menyala \\
\hline 4. & 5 Meter & Berhasil terkoneksi & Semua lampu menyala \\
\hline 5. & 6 Meter & Berhasil terkoneksi & Semua lampu menyala \\
\hline 6. & 7 Meter & Berhasil terkoneksi & Semua lampu menyala \\
\hline 7. & 8 Meter & Berhasil terkoneksi & Semua lampu menyala \\
\hline 8. & 9 Meter & Berhasil terkoneksi & Data Terputus \\
\hline 9. & 10 Meter & Gagal terkoneksi & Semua lampu mati \\
\hline
\end{tabular}

\section{KESIMPULAN}

1. Alat ini dapat menggantikan saklar - saklar yang ada dirumah dengan demikian kita tidak perlu lagi berdiri untuk mematikan dan menyalakan lampu rumah yang ada dirumah kita karena saklar sudah ada digenggaman kita sendiri atau dikatakan Smartphone Android.

2. Terdapat jedah waktu pada saat Smartphone mengirim kode karakter untuk menghidupkan dan mematikan lampu, ini disebabkan karena dalam program mikrokontroler diberi waktu delay sebesar 1000 milisecond (1 detik) yang bertujuan untuk memberi ruang kinerja mikrokontroler sebelum memproses data selanjutnya.

3. Untuk saat ini alat ini belum dapat mengontrol peralatan listrik yang memiliki daya besar berhubung tidak menggukan relay.

\section{DAFTAR PUSTAKA}

[1] Masinambow V., "Pengendalian Saklar ListrikmMelalui Ponsel Pintar Android”, Ejournal Teknik Elektro dan Komputer, 2301-8402, 2014

[2] Novelan, M. S., Tulus., E M Zamzam. (2018). Control of motion stability of the line tracer robot using fuzzy logic and kalman filter. Journal of Physics: Conference Series, 978(1), 012066. Retrieved from https://iopscience.iop.org/article/10.1088/17426596/978/1/012066

[3] Novelan, M. S., Husein, A. M., Harahap, M., \& Aisyah, S. (2018). SMS Security System on Mobile Devices Using Tiny Encryption Algorithm. Journal of Physics: Conference Series, 1007(1), 12037. Retrieved from http://stacks.iop.org/1742$6596 / 1007 / \mathrm{i}=1 / \mathrm{a}=012037$

[4] Sawidin S., Engelin Melo O., dan Marsela T., "Monitoring Kontrol Greenhouse untuk Budidaya Tanaman Bunga Krisan dengan LabView”, J NTETI , Vol. 4, No. 4, November 2015.

[5] Supriono, Seno D. Panjaitan, "Manajemen Daya Listrik dengan Sistem Automatic Transfer and Synchronization Switch berbasis PLC", JNTETI, Vol. 4, No. 3, Agustus 2015 